\title{
EDUCATION IN SERBIA AS FOUNDING PRINCIPLE OF THE LOCAL ECONOMIC DEVELOPMENT
}

\author{
Hajnalka KOVÁCS SÁRKÁNY ${ }^{\mathrm{a}}$, Vilmos KOVÁCS ${ }^{\mathrm{a}}$ \\ ${ }^{\text {a }}$ University of Debrecen, AGTC, Hankóczy Jenő Doctoral School of Crop, Horticulture and Food \\ Sciences,Böszörményi út 138, 4015 Debrecen, phone: +381(0) 63460 797, +381(0) 63580 729, e-mail: \\ hajnalka.kovac@gmail.com, vilmos.kovac@gmail.com
}

Cite this article: Kovács Sárkány, H., Kovács, V. (2015). Education in Serbia as Founding Principle of the Local Economic Development. Deturope, 7, 2: 81-94

\begin{abstract}
The aspiration of Serbia to join the European Union requires the transformation of the educational system of the country to adapt EU mechanisms. Such endeavours are reflected in the Law on Higher Education modificated in July 2013 and Law on Adult Education, wich is published in 2014. These may infer social and economic consequences on a wide scale. Our intention was to present the structure of the Serbian education system and the distribution of the educational level of the population applying secondary data analysis in our study. Furthermore, our goal was to shed light on a particular section of the Law on Higher Education which regulates the recognition of foreign degree (diploma); in addition, we intended to touch upon the issue of trainings in non-formal education controlled by the Law on Adult Education. Lastly, we addressed changes in the unemployment rate and levels of qualification of those without a job. Our work is applied from the perspectives of knowledge and knowledge transfer; since local economic development depends highly on the accumulated pieces of information acquired by experts.
\end{abstract}

Keywords: Serbia, education system, university, economic development

\section{THE STRUCTURE OF THE SERBIAN EDUCATION SYSTEM}

The primary pedagogical-educational system is of a unitary nature with eight years of primary school attendance with learners admitted at their age of seven.

It is followed by secondary schooling. The secondary (specialized) education is divided into three and four year training (SORS, 2014).

Secondary education is realized within the following institutional framework: gymnasium, vocational school, arts school, and mixed schools (gymnasium and vocational school or arts school). Profession can also be acquired, - in its classical sense- (it has to be preceded by two years of work experience) by one or two year specialist training, so called master vocational training after whose completion students take a specialist - master exam. 
In accordance with the regulation of the adult education, individuals who have not completed their primary or secondary studies can apply for the admittance to an adult primary or secondary training.

Higher education activities carried out through academic and professional career courses based on the approved and/or accredited study programmes for acquiring higher education.

The Law on Higher Education divides academic studies into three stages:

1. First level studies or courses shall include:

- basic academic courses (BSc); and

- basic professional career courses.

2. Second level studies or courses shall include:

- diploma academic courses for a master's degree (MSc);

- specialist professional career courses;

- specialist academic studies.

3. Third level courses shall include doctoral academic courses $(\mathrm{PhD})$ (Law on Higher Education, 76/2005).

The required amount of credits for the basic academic studies is set to $180-240$ ECTS $^{15}$ credits, while for the basic professional career 180 ECTS credits.

The required amount of credits for the MSc degree is 60-120 ECTS, which depends on the number of points obtained following the foundational courses. Nonetheless, to get hold of a Master Degree, candidates are required to collect 300 ECTS credit.

Doctoral studies shall be given 180 ECTS credits at least, with a compulsory previous total of at least 300 ECTS credits earned through the core academic and master's degree courses.

The levels of the educational achievement are ranked on a scale from I. - VIII. on the territory of the Republic of Serbia.

The Higher Education National Committee accorded each of the higher education level rendered in Figure 1.

\footnotetext{
${ }^{15}$ European Credit Transfer and Accumulation System
} 
Figure 1 National framework of qualifications

\begin{tabular}{|c|c|c|c|c|c|}
\hline $\begin{array}{c}\text { Level of } \\
\text { professional } \\
\text { degree }\end{array}$ & \multicolumn{2}{|c|}{$\begin{array}{l}\text { Faculty/art } \\
\text { academy/college/university }\end{array}$} & \multicolumn{2}{|c|}{ College } & $\begin{array}{c}\text { Framework } \\
\text { of EU } \\
\text { qualifications } \\
\text { (levels) }\end{array}$ \\
\hline VIII & $\begin{array}{l}\text { Doctor of } \\
\text { Sciences }\end{array}$ & - & - & - & \multirow{2}{*}{8} \\
\hline VII-2 & $\begin{array}{l}\text { Master of } \\
\text { Sciences }\end{array}$ & Specialization & - & - & \\
\hline \multirow{2}{*}{ VII-1 } & \multirow{3}{*}{ II level } & \multirow{4}{*}{$\begin{array}{l}\text { Regular } \\
\text { studies }\end{array}$} & & - & 7 \\
\hline & & & & \multirow{3}{*}{$\begin{array}{l}3 \text { year } \\
\text { studies }\end{array}$} & 6 \\
\hline VI-2 & & & Specialization & & \\
\hline VI-1 & I level & & $\begin{array}{l}2 \text { or } 5 \text { year } \\
\text { studies }\end{array}$ & & 5 \\
\hline
\end{tabular}

Source: ENC- National Committee on Higher Education

Non-higher education system encompasses the I.-V. levels of professional degree defined by the Law on Secondary Pedagogy and Education, as follows:

V. level of professional degree: specialization studies;

IV. level of qualification: secondary education of four years;

III. level of qualification: secondary education of three years;

II. level of qualification: professional education of two years;

I. level of qualification: vocational training of one year.

\section{THE EDUCATIONAL LEVEL OF THE SERBIAN CITIZENS}

The educational level of the Serbian citizens, according to the Statistical Register of Republic of Serbia (SORS), has been showing a steady rise considering the census of 2011. The increase of the educational level is represented in Table 1, in comparison with figures from 1991. 
Table 1 Population aged 15 and above by educational attainment, according to the censuses of 1991 and 2011.

\begin{tabular}{|l|r|r|}
\hline & $\mathbf{1 9 9 1}$ & \multicolumn{1}{|c|}{$\mathbf{2 0 1 1}$} \\
\hline Republic of Serbia & 6294350 & 6161584 \\
\hline Without educational attainment & 590682 & 164884 \\
\hline Incomplete primary education & 1522639 & 677499 \\
\hline Primary education & 1541778 & 1279116 \\
\hline Secondary education & 2022048 & $3015092^{16}$ \\
\hline High education (college) & 241416 & 348335 \\
\hline $\begin{array}{l}\text { Higher education } \\
\text { (university studies) }\end{array}$ & 322888 & 652234 \\
\hline Unknown & 52899 & 24424 \\
\hline
\end{tabular}

Source: Author's own construction based on SORS, 2013 data.

In line with registered data during the course of twenty years, the increase in the educational level seems even more salient, represented in Table 2.

Table 2 Population aged 15 and above by educational attainment, according to the censuses of 1991 and 2011 - expressed in percentages and the percentage difference of data of the two years observed.

\begin{tabular}{|l|r|r|r|}
\hline & \multicolumn{1}{|c|}{$\mathbf{1 9 9 1}$} & \multicolumn{1}{|c|}{$\mathbf{2 0 1 1}$} & Difference \% \\
\hline Republic of Serbia & $100 \%$ & $100 \%$ & 6,7 \\
\hline Without educational attainment & 9,38 & 2,68 & 13,19 \\
\hline Incomplete primary education & 24,19 & 11,00 & 3,73 \\
\hline Primary education & 24,49 & 20,76 & $-16,8$ \\
\hline Secondary education & 32,13 & 48,93 & $-1,81$ \\
\hline High education & 3,84 & 5,65 & $-5,46$ \\
\hline Higher education & 5,13 & 10,59 & 0,44 \\
\hline Unknown & 0,84 & 0,40 & \\
\hline
\end{tabular}

Sources: Author's own construction based on SORS, 2013 data.

\footnotetext{
${ }^{16}$ Presented are data for persons who completed secondary school and for persons who completed specialisation after secondary school.
} 
The numbers of those without a primary level degree or without completed primary studies have significantly decreased, while the number of those who successfully terminated their secondary formation shows a notable increase. On top of this, the number of those who finalized their second or third level (high education and higher education) studies has doubled.

Nonetheless, the number of those who completed their academic studies still remains under the statistical level of the Hungarian graduates in point of the ratio of population (KSH, 2013).

The percentage difference between those who do not graduate from primary school and those who complete their primary education is quite high rising to cca. $35 \%$, while the percentage ratio of pupils graduating from secondary school reaches $50 \%$.

The structure of the educational level of the population is shown in Figure 2.

Figure 2 Structural distribution of the educational level of the population

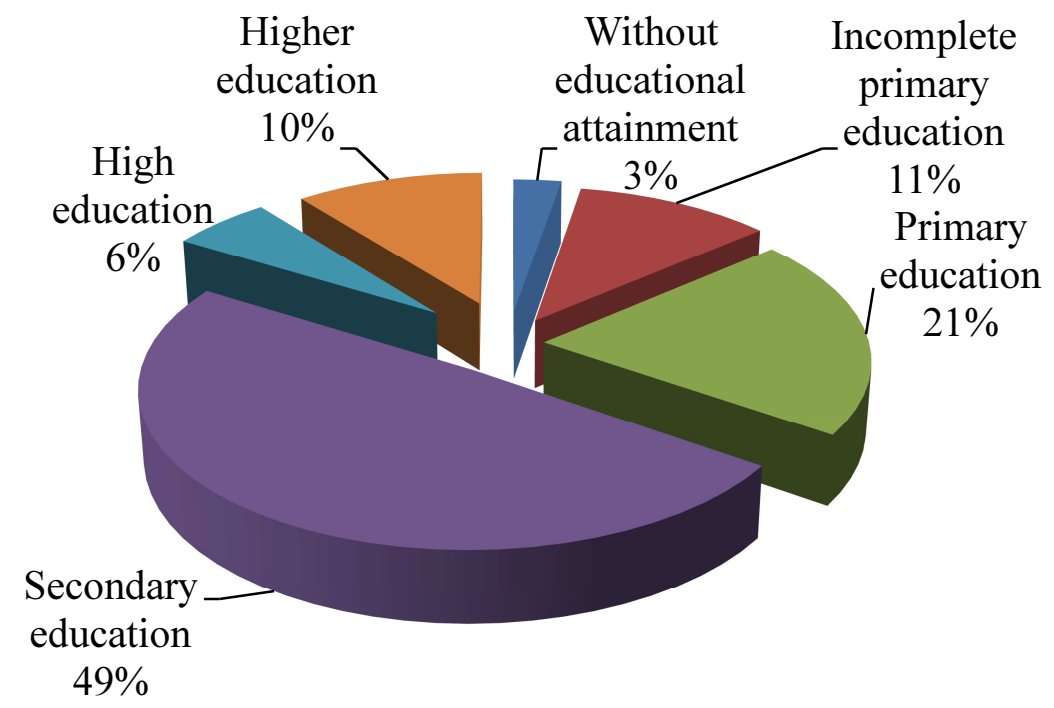

Source: Author's own construction based on SORS, 2013 data

\section{RECOGNITION OF FOREIGN HIGHER EDUCATION DOCUMENTS AND THE LAW ON HIGHER EDUCATION}

The fact that the number of professionals holding academic (college or university) degree could somewhat be higher and requires special attention, because degrees obtained in foreign countries in Serbia do not successful undergo domestic recognition process. 
"In Serbia, technically, though, the term "recognition" is in use, practically, however, the process of recognition is necessary to hold a foreign qualification which must be in compliance with a domestic diploma or qualification. Consequently, the process of recognition is demanding and takes long. In case of a mismatch, the university, which is processing the recognition, may require additional testing. However, in case of interdisciplinary diplomas, in praxis, recognition is in many cases impossible." (Maksimović, 2012, p. 62)

According to the Law on Higher Education recognition of a foreign document of higher education means a procedure on the basis of which the right of the holder of that document shall be established to continue education and/or to seek employment.

Any higher education degree got in the SFRJ till April 27th, 1992, in the Federal Republic of Yugoslavia, or in Serbia and Montenegro - till June 16th, 2006, or in Republic of Serbia is not subject to the domestic higher recognition process or diploma naturalization (Law on Higher Education, 76/2005).

In accordance with the regulation of the law "the evaluation of a foreign study program is carried out on the basis of the type and level of the acquired knowledge and skills taking into account the educational system of the country where the foreign diploma was issued, the conditions of admittance, competencies acquired by the end of the study program, rights stemming from and by the foreign higher degree, and other relevant facts, without considering formal notations and structures of the study program (Law on Higher Education, 76/2005).

The law distinguishes two types of recognition:

- Evaluation of the entire foreign study program or part of it, for those whose aim is to pursue further studies, is accomplished by an expert body of an independent higher educational institution to which the academic degree request was sent. Law from 2013 stipulates that the evaluation of a foreign study program, with the aim of seeking employment, is carried out by the National Centre for Certification of Foreign Higher Educational Degrees (ENIC/NARIC center), acting as an organizational unit within the scope of the Ministry. Such a development brought a good deal of change; thus, it was inevitable to include it within the framework of the law in question. Furthermore, it was necessary to define such cases of recognition which did not have precedence so far: "For the matter of providing professional opinion in the course of the evaluation of a foreign study program for employment purposes, the minister summons a committee of at least three academic professors from the relevant field, who are enlisted in the Serbian Conference of Universities" (Law on Higher Education, $76 / 2005)$. 
A completed evaluation of a certain study program is to be considered valid in subsequent cases of recognition of a foreign higher educational degree obtained within the scope of the same scrutinized study program.

- The recognition of a foreign higher educational degree for employment (professional recognition) is in the jurisdiction of the Ministry through the ENIC/NARIC centre. Professional recognition is carried out according to the previously established criteria of the evaluation of a foreign study program.

This approach would accelerate the recognition process, since if the application was submitted properly a decision is required to be made within 90 days; on top of that, the decision of the professional recognition body is to be treated as final.

\section{ADULT EDUCATION AND THE LAW ON ADULT EDUCATION}

The first law related to adult education system cames into force in 2013, and called Law on Adult Education. This law acknowledges the term Life Long Learning, whose framework provides an opportunity to obtain skills within a formal, non-formal, and informal education. Formal education is intended to be accomplished within the framework of a primary and secondary education, while its non-formal counterpart offers an entirely separate educational program.

The practical application of the Law on Adult Education seeks to accomplish the following:

1. Enhancement of the educational and qualification structures and the advancement of employment possibilities of the citizens;

2. Foundation of a sustainable socio-economic development of the Republic of Serbia;

3. Enhancement of the professional mobility and flexibility of the working population;

4. Decrease of poverty, establishment of equality, social inclusion, and inter-generational solidarity;

5. Enhancement of the quality of life - personal, family, and of the natural and social habitat;

6. Development of democracy, inter-cultural understanding and tolerance;

7. Integration into the European social and economic space with the appreciation of the European Educational Framework (Law on Adult Education, 55/2013).

The law, besides regulating educational forms and the acquisition of a degree within a formal education, also prescribes forms of education within non-formal training whose completion would provide competencies and skills that would be beneficial to develop 
occupation (practice) related knowledge, acquire supplementary knowledge, or to help find a different employment.

According to the Law on Adult Education, the organizer of educational activities may be:

1. Primary and secondary schools;

2. Other institutions ( public agencies, public firms, organizations responsible for employment issues, employment agencies, economic societies, carriers of professional rehabilitation affairs, entrepreneurs, trade union organizations, societies, professional bodies, organizations for adult education ( public, workers', or open universities, universities for the third era, etc.), centres and organizations for professional development, for foreign language acquisition, for information-communication technology, for the training and development of human resources, driver training firms, chambers of commerce, centres for carrier management and advice, societies of employers, cultural-educational centres, culture centres, and other subjects registered and adhering to the criteria of educational activities (Law on Adult Education, $55 / 2013)$.

In order to a company to accomplish non formal education, it has to adhere to licensing procedures in accordance with the Law on Education.

The process of issuance of a licence to an organization to acquire the status of a publicly recognized organizer of educational activities is to be initiated with an application submitted to the Ministry.

The program proposal for educational activities in adult education contains an adult educational plan and a program. Furthermore, it is necessary to compile a syllabus of its accomplishment, to adhere to conditions required to carry out adult educational activities, to hold necessary pieces of equipment and tools, as well as to hire an appropriate number of qualified personnel who would be responsible to conduct educational activities.

The Ministry, afterwards, hands over a part of the request to the Office for Educational and Pedagogical Development, which informs about the adult education plans and programs and about their implementation, for further consideration.

After receiving an approval from the Office for Educational and Pedagogical Development, the application is handed over to the supervisor of the Ministry to determine other requirements to be fulfilled to grant the licence.

The Minister is required to make a decision if the licence is granted, based on the findings of the educational supervisor, in three months from the submission of the application. 


\section{LABOUR MARKET REGISTER}

The National Employment Service (NES) stores data on the number of unemployed on the territory of Republic of Serbia represented in Figure 3:

Figure 3 General unemployment characteristics from 2005 to October 2014

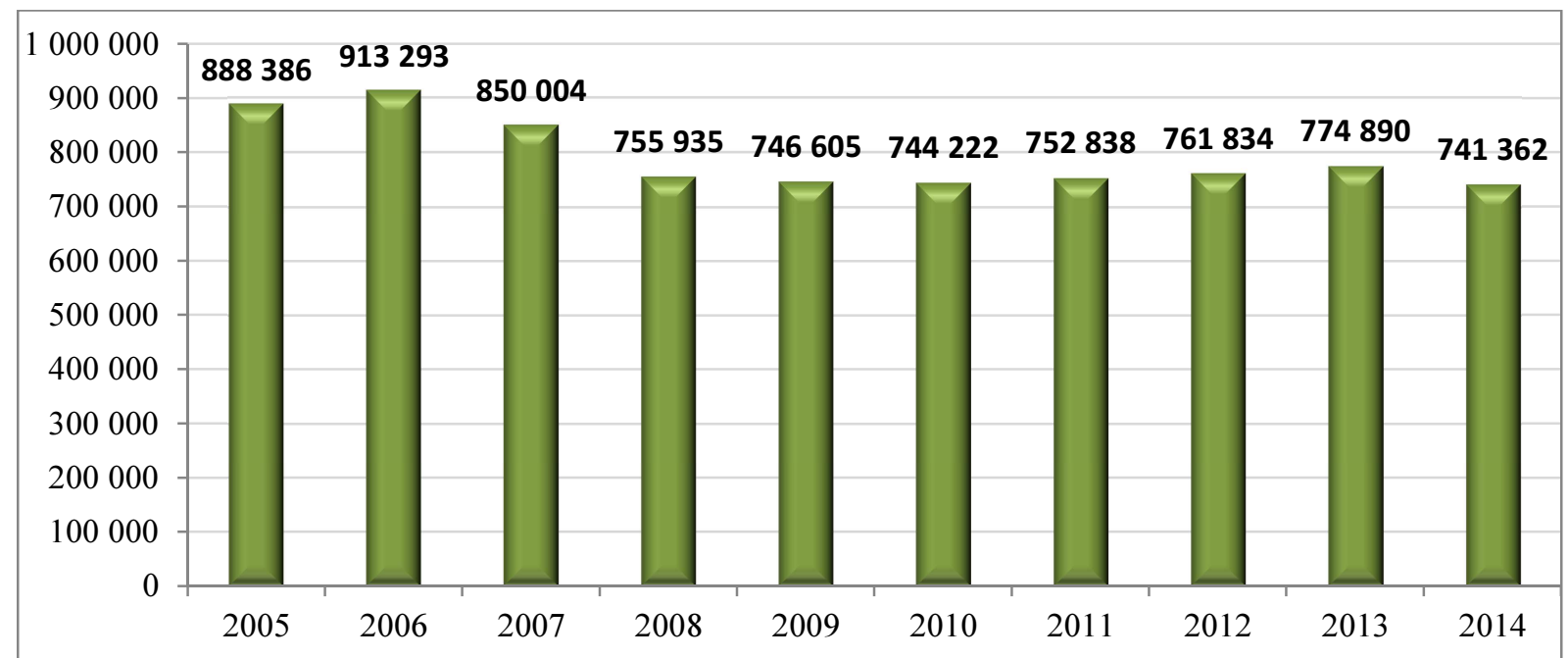

Sources: Author's own construction based on NES data

We may conclude that there were 147024 less unemployed on the territory of Republic of Serbia in October 2014 with respect to 2005. Though, we must remark that the decreasing tendency in the unemployment rate may be due to emigration (in living or educational purposes), and also due to the fact that employment in the neighbouring countries is open to citizens living close to the border territories.

The educational level of the unemployed is best shown on the following Figure of November 2014 (Fig. 4). 
Figure 4 Number of unemployed by qualification in November 2014.

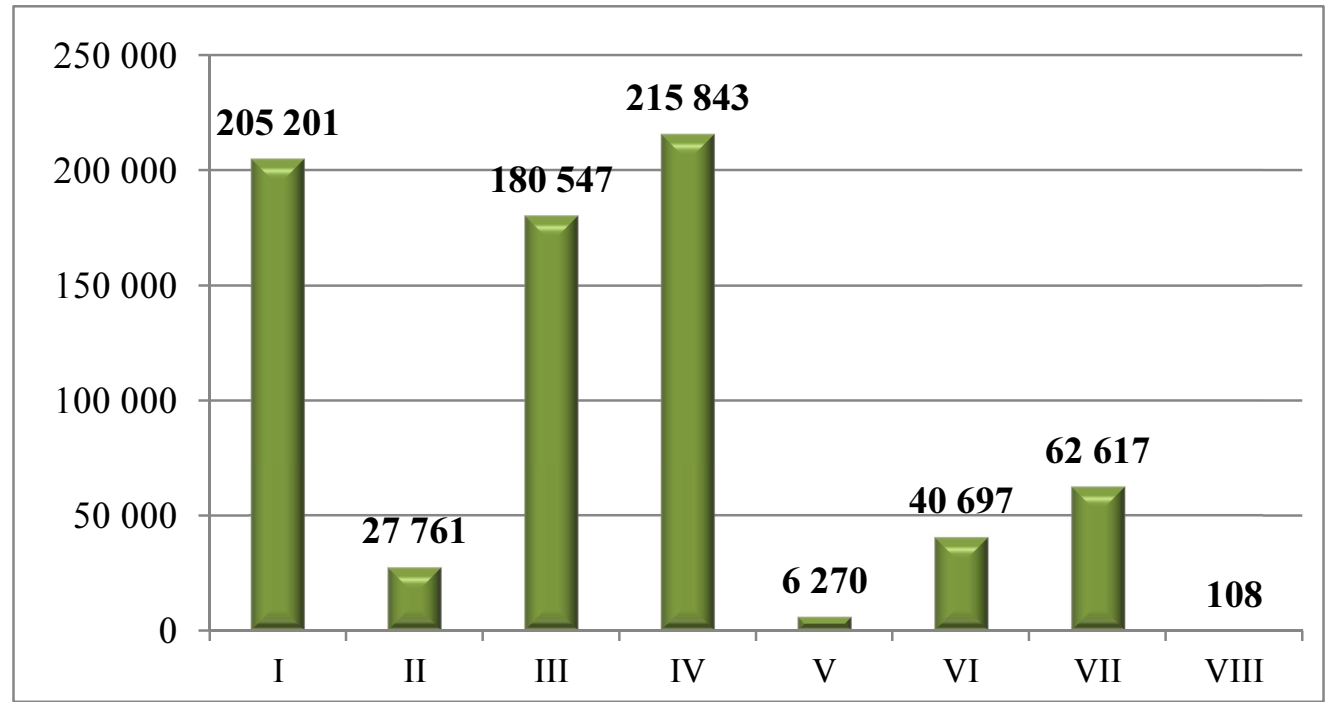

Source: Author's own construction based on NES data

According to percentage distribution, it signifies shown on the following Figure.

Figure 5 Number of unemployed by qualification in November 2014.

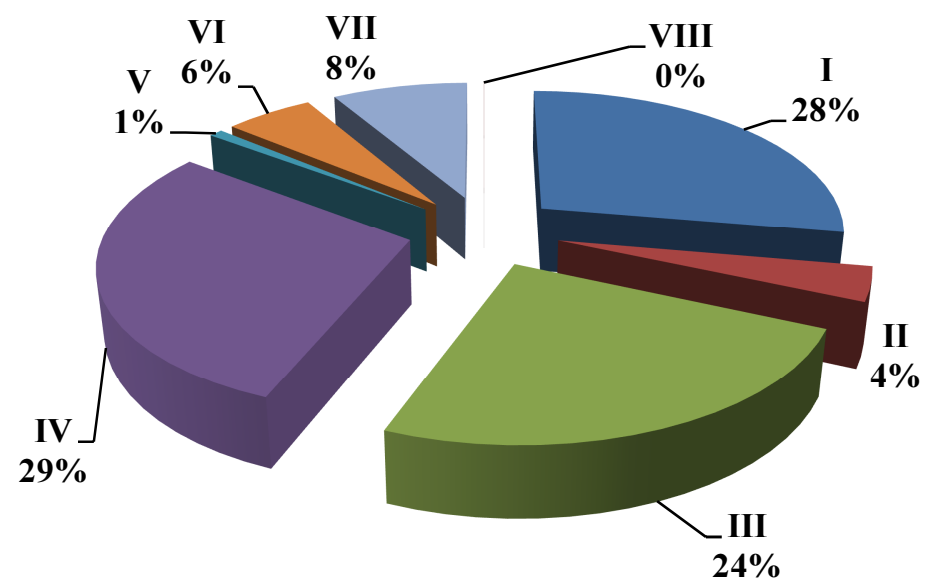

Source: Author's own construction based on NES data

$85 \%$ percent of the unemployed are constituted of job seekers with an I.-IV. education level.

The National Employment Service (NES) database makes it possible to gain a precise insight into the unemployment rate of each of the occupational sector, demonstrated by Table 3. 
Table 3 Unemployment, vacancy filling requests from job matching services by occupation groups during November 2014

\begin{tabular}{|c|c|c|c|c|c|}
\hline & Occupation groups & $\begin{array}{l}\text { Unemployd } \\
\text { persons }\end{array}$ & & Occupation groups & $\begin{array}{l}\text { Unemploy } \\
\text { d } \\
\text { persons }\end{array}$ \\
\hline 1. & $\begin{array}{l}\text { Agriculture, } \\
\text { production and processing }\end{array}$ & 41.389 & 11. & $\begin{array}{lr}\text { Trade, hotels } \quad \& \\
\text { restaurants } \\
\text { tourism }\end{array}$ & 67.596 \\
\hline 2. & $\begin{array}{l}\text { Forestry and wood } \\
\text { processing }\end{array}$ & 8.810 & 12. & $\begin{array}{l}\text { Economics, law and } \\
\text { administration }\end{array}$ & 81.516 \\
\hline 3. & $\begin{array}{l}\text { Geology, mining and } \\
\text { metallurgy }\end{array}$ & 3.759 & 13. & $\begin{array}{l}\text { Education and } \\
\text { upbringing }\end{array}$ & 14.493 \\
\hline 4. & $\begin{array}{l}\text { Mechanical engineering } \\
\text { and metal processing }\end{array}$ & 98.710 & 14. & $\begin{array}{l}\text { Social and humanistic } \\
\text { field }\end{array}$ & 10.789 \\
\hline 5. & $\begin{array}{l}\text { Electrotechnical } \\
\text { engineering }\end{array}$ & 37.562 & 15. & $\begin{array}{l}\text { Mathematics and } \\
\text { other natural sciences }\end{array}$ & 12.553 \\
\hline 6. & $\begin{array}{l}\text { Chemistry, non-metals and } \\
\text { typography }\end{array}$ & 21.43 & 16. & Culture, art and media & 8.498 \\
\hline 7. & $\begin{array}{l}\text { Textile and leather } \\
\text { processing }\end{array}$ & 35.608 & 17. & $\begin{array}{l}\text { Health, pharmacy amd } \\
\text { social protection }\end{array}$ & 23.896 \\
\hline 8. & $\begin{array}{l}\text { Public utility, upholstery } \\
\text { and painting services }\end{array}$ & 3.142 & 18. & Fitness and sports & 795 \\
\hline 9. & $\begin{array}{l}\text { Geodesy and civil } \\
\text { engineering }\end{array}$ & 17.297 & 19. & Other & 232.493 \\
\hline 10. & Transport & 18.701 & - & - & - \\
\hline
\end{tabular}

Source: Author's own construction based on NES data

\section{CONCLUSIONS, AFTERWORD}

Serbia has significantly decreased the number of people holding only a completed or partially completed primary level degree. In the same time, the number of high-school graduates has notably increased. 
There is a lack of accurate statistical data or database on the number of people with a higher degree mostly because the number of the exact cases where the diploma naturalization was unsuccessful or just haven't been completed yet is still unknown.

The government recognizing the obstacles behind the recognition process has established a centre (office), in accordance with the Law on Higher Education from 2013 with the aim of simplified recognition procedures for employment purposes, which would function independently and differently from existing practices and also out of the scope of colleges and universities. However, after one and a half years of enacting the law, i.e. till February 2015 the ENIC/NARIC centre has not started its functioning. If we put this fact into the perspectives of a foreign investor, we may conclude that the simplicity and promptness of recognition process would provide beneficial conditions to ameliorate employment conditions.

In our view, the Law on Adult Education aims at putting adult education into practice within the frames of formal education (primary and secondary), aspiring to help those individuals who have not completed their primary education, on top of which they could seek further specialization at a secondary level, since "it is indispensable that the citizens of the region be as much educated as possible" (Pecsenyánszky, 2014, p.23.).

Regarding non formal education system, it seems that time has stopped, since we have no evidence of a firm that has obtained a permit to engage in adult education. It is, though, foreseeable, that degrees obtained within the framework of a non-formal education could provide for adequate demands of special skills and knowledge. Educational methods adopted in a non-formal educational environment are able to respond the most efficiently to labour market demands. In line with this, to our mind, non-formal education would act as a great facilitator among employees, since after a success in finding a workplace; individuals would be required to continue their training to adapt themselves to new professional conditions by permanent and vocational training.

If we compare the percentage rates of the education level of the unemployed with the education level of the rest of the population, we may conclude that they overlap with each other; in other words, on the rough estimate the percentage distribution is almost the same. However, by examining the unemployment rate in each employment sector, it becomes obvious that in case of some professions the unemployment is rather high. Some possible solutions could include retraining and reskilling and the acquisition of further useful competencies. 
As Takács concluded, the solution for those who are enlisted in the unemployment database would be a well-organized and institutionalized adult educational infrastructure (Takács, 2008, p. 291.).

All in all, education plays a significant role in local economic growth, whose development would determine the pace at which those who seek employment would be able to adapt themselves to the demands of the labour market. It is in a direct correlation with local economic development, since local economy can only prosper in a progressed educational milieu.

With the new Law on Adult Education coming into force the unemployment rate in Serbia is expected to fall significantly, mainly thanks to retrainings.

\section{REFERENCES}

ENC- Educational National Committee, Retrieved Februar 17, 2015 from http://nsvo.etf.rs/

KSH- Központi Statisztikai Hivatal- Hungarian Central Statistical Office (2013) 2011. évi népszámlálás 7. Iskolázottsági adatok (Population census 2011. $7^{\text {th }}$ Education data) Retrieved Februar $\quad 17, \quad 2015$ from http://www.ksh.hu/docs/hun/xftp/idoszaki/nepsz2011/nepsz_07_2011.pdf

Law on Adult Education - Zakon o obrazovanju odraslih (Official Gazette of the Republic of Serbia, No. 55/2013)

Law on Higher Education - Zakon o visokom obrazovanju (Official Gazette of the Republic of Serbia, No. 76/2005, 100/2007 97/2008, 44/2010, 93/2012, 89/2013)

Law on Secondary Pedagogy and Education - Zakon o srednjem obrazovanju i vaspitanju (Official Gazette of the Republic of Serbia, No. 55/2013)

Maksimović, I. (2012). Praksa Srbije u priznavanju stranih visokoškolskih isprava (Serbian practice in recognition of foreign higher education documents) In: B. Emita- I. Maksimović Priznavanje stranih visokoškolsih isprava u Srbiji i Hrvatskoj, Grupa 484, Beograd. Retrieved Februar 17, 2015, from

(http://grupa484.org.rs/sites/default/files/Priznavanje\%20stranih\%20VS\%20isprava\%20 u\%20SR\%20i\%20HR,\%202012..pdf

NES- Nacional Employment Service, Republic of Serbia, Monthly Statistic Bulletin Nevember 2014. No.147. Unemployment and employment in the Republic of Serbia, Retrieved Februar 17, from http://www.nsz.gov.rs/live/digitalAssets/3/3041_bilten_nsz_novembar_2014.pdf

Pecsenyánszky, M.(2014). (The opportunity of the agricultural training in the shouthern parts of Heves country) A mezögazdasági szakképzés lehetösége a dél-hevesi térségben. Economica, (VII). 3. 19-23.

SORS- Statistical Office of the Republic of Serbia (2013). 2011 Census of Population, Households and Dwellings in the Republic of Serbia- Population- Educational attaintment, literacy and computer literacy, Belgrade 2013. Retrieved februar 17, 2015 from

http://pod2.stat.gov.rs/ObjavljenePublikacije/Popis2011/Skolska\%20sprema,\%20pisme nost $\% 20 i \% 20$ kompjuterska\%20pismenost-

Educational\%20attainment,\%20literacy\%20and\%20computer\%20literacy\%20.pdf 
SORS- Statistical Yearbook of the Republic of Serbia- Education (2014) Retrieved Februar 17, 2015 from http://webrzs.stat.gov.rs/WebSite/repository/documents/00/01/54/01/05Obrazovanje.pdf

Takács, Z. (2008). A munkaerő kompetencia és az oktatás viszonya (Relationship between education and labor skills) In: Regionális erőnlét (Ed.) Gábrity Molnár, I.- Mirnics, Zs. MTT, Szabadka 